75 years of Agricultural University - Plovdiv JUBILEE SCIENTIFIC INTERNATIONAL CONFERENCE Plovdiv 26-28 November 2020
PERSPECTIVES ON AGRICULTURAL SCIENCE AND INNOVATIONS FOR SUSTAINABLE FOOD SYSTEMS

\title{
DOI: 10.22620 /agrisci.2021.29.006 \\ COMMON DISEASES OF SNAP BEAN (PHASEOLUS VULGARIS L.) FOR BIOLOGICAL PRODUCTION
}

\author{
Olga Georgieva*, Natalia Karadzhova
}

Maritsa Vegetable Crops Research Institute (MVCRI) - Plovdiv

*E-mail: olgaizk@abv.bg

\begin{abstract}
The main diseases of snap bean (Phaseolus vulgaris L.) for organic production and the possibilities for control have been studied. The strategic directions of the experimental work included: monitoring of diseases; study of pathogens' variability; the field resistance of the Bulgarian bean varieties "Evros" and "Tangra" to the diseases in organic farming; optimization of the phytosanitary state of the crop through the authorized plant protection products. It has been established that seedborne diseases are of predominant importance for organically grown garden beans. These are bacterial blight Xantomonas axanopodis pv. phaseoli, halo blight Pseudomonas syringae pv. phaseolicola and anthracnose Colletotrichum lindemuthianum. The screening of Bulgarian bean varieties for disease resistance showed that the "Evros" variety is relatively resistant to bacterial blight and anthracnose, which makes it suitable for growing by biological technologies. The development of bacterial blight and anthracnose after five treatments with the fungicide Bordeaux Mix 20VP (Bordeaux mixture 200 $\mathrm{g} / \mathrm{kg} \mathrm{Cu}+$ ) with an interval of 10-14 days, starting from the flowering phase, is in the range up to $12.5 \%$.
\end{abstract}

Keywords: organic farming, Phaseolus vulgaris, diseases, field resistance, fungicides.

\section{INTRODUCTION}

The development of diseases is one of the main reasons for reduced yields of snap bean. Snap bean are attacked by a large number of fungal, bacterial, viral diseases and a number of pests, but depending on soil, climatic and production conditions, not all are of economic importance. The most economically important for our country diseases of snap bean are common bean mosaic virus (BCMV), yellow bean mosaic virus - Bean yellow mosaic virus (BYMV), cucumber mosaic - Cucumber mosaic virus (CMV); bacterial blight Xantomonas campestris pv. phaseoli (Smith), halo blight - Pseudomonas syringae pv. phaseolicola (Burkhoider) Dowson., anthracnose - Colletotrichum lindemuthianum, rust - Uromyces appendiculatus and root rot, caused by Fusarium solanum sp. phaseoli
(Burkholder) (Sofkova et al., 2014). In the areas with irrigated agriculture, the causes of bacterial blight - Xanthomonas axanopodis pv. phaseoli (Xap) (Vauterin et al., 2000) and the halo blight of Pseudomonas savastanoi pv. phaseolicola (Psp) (González et al., 2004; Petrenkova et al., 2009). According to literature data, inheritance of resistance to Xap is horizontal (Kiryakov, 1999). Regarding the cause of halo Pseudomonas savastanoi pv. phaseolicola is known to have been found a resistance oligogen Prg., and among the crosses of tolerant and resistant bean varieties a recessive ppt gene has been identified controlling tolerance to races 1 and 2 of the Pseudomonas savastanoi pv. phaseolicola. Resistance to anthracnose Colletotrichum lindemuthianum Saccardo et Magnus is a monogenic dominant trait that is controlled by the Are gene, responsible for resistance to 6 of 
75 years of Agricultural University - Plovdiv JUBILEE SCIENTIFIC INTERNATIONAL CONFERENCE Plovdiv 26-28 November 2020
PERSPECTIVES ON AGRICULTURAL SCIENCE AND INNOVATIONS FOR SUSTAINABLE FOOD SYSTEMS the 8 known races of the pathogen. In Bulgaria, 7 races of the pathogen have been identified, of which race 8 is the most common (Kiryakov, 2000; Kiryakov and Genchev, 2004), and the Bulgarian varieties of field beans Danube 1, Biser and Trudovets (Kiryakov and Genchev, 2002) are resistant to it. ). Growing beans as a monoculture leads to the accumulation in the soil of the pathogen Fusarium solani f. sp. faseoli (Burkholder), causing dry Fusarium rot. Two dominant genes, Fop1 and Fop2, have been found to determine the resistance of beans to the Brazilian and American races of the pathogen (Kling, 2010). Rust Uromyces appendiculatus (Strauss) on beans has limited economic importance for Bulgaria due to its later manifestation. The fungus is characterized by significant pathogenic diversity, with 7 races found in the country (Kiryakov and Genchev, 2003). The varieties "Halo", "Tarnovo"13, "Abritus", "Prelom", "Dunav 1" and others are resistant to the races widespread in Bulgaria (Kiryakov \& Genchev, 2004). In recent decades, the practice adopted so far for chemical plant protection has been replaced by a biological direction for growing vegetables. In plant protection technologies, the importance of the biological method for disease control is growing, which is a set of measures aimed at maintaining optimal conditions for development and increasing plant immunity through the use of ecological methods and tools: sustainable varieties, biopreparations, growth regulators and biofertilizers (Akhter et al., 2015; Latorre \& Jones, 1979; Pakhnenko, 2001). Growing of vegetable crops by biological technology is characterized by low stability of the phytosanitary condition of the crops, accompanied by the mass multiplication of diseases, due to the limited set of possible authorized means for their control (Gent \& Schwartz, 2005; van Bruggen \& Semenov, 2000; Semenov et al., 2016). The monitoring of diseases in agrosystems and the diagnosis of soil, seeds and crops is of principal importance in the choice of plant protection products (Finck \& van Bruggen, 2015; van Diepeningen et al., 2006). In the present work we set the goal of identifying the main diseases of beans for organic production and assessing the potential of Bulgarian varieties for growing by biological technology.

\section{MATERIALS AND METHODS}

During the vegetation 2019-20 the possibility for growing the varieties of garden beans "Euros" and "Tangra" from the selection - genetic collection of IZK Maritsa by organic (biological) technology was studied. The experiment is based on a randomized block map in two replications at a plot size of $4.2 \mathrm{~m} 2$. The plants are grown according to the technology adopted for garden beans on a high two-row bed and agricultural techniques. The experiment is set as a comparative experiment for growing beans using conventional and biological technology.

Phytopathological observations and reports of major bean diseases were performed. The degree of defeat from bacterial blight and anthracnose was reported on a 4-point scale on Chekalin (Chekalin, 2003): $0-10 \%$ without symptoms or very weak; 1 - from $11 \%$ to $25 \%$ of the surface with spots; 2 - from 26 to $50 \%$ of the surface with spots; 3 - from 51- to 75\%, 4over $75 \%$ of the surface with spots.

The attack index was calculated according to McKinney's formula. Resistance to the disease was determined by the following scale: BB - over $75 \%$, highly susceptible, B $51 \%-75 \%$, susceptible, C - 26\% $-50 \%$, moderately susceptible, Y $-11 \%-25 \%$, stable, UU - 10\%, highly stable. In dry Fusarium rot, the percentage of dried plants (\%) was calculated.

\section{Fungicide treatments}

Conventional technology: Bordeaux Mix 20VP 300g / da $741 \mathrm{~g} / \mathrm{kg}$ Bordeaux mixture $(200 \mathrm{~g} / \mathrm{kg} \mathrm{Cu})+$, Fuguran $\mathrm{OH} 50 \mathrm{VP}$ 
75 years of Agricultural University - Plovdiv JUBILEE SCIENTIFIC INTERNATIONAL CONFERENCE Plovdiv 26-28 November 2020
PERSPECTIVES ON AGRICULTURAL SCIENCE AND INNOVATIONS FOR SUSTAINABLE FOOD SYSTEMS
300 g / da Copper oxychloride, Topaz 100EK Penconazole 50ml / da, Ortiva Plus 200 g / 1 azoxystrobin and $125 \mathrm{~g} / 1$ difenoconazole 100 $\mathrm{ml} /$ Ha with an interval of 10-14 days.

Biological technology: five treatments with Bordeaux Mix 20VP 300g / Da with an interval of 10-14 days.

\section{RESULTS AND DISCUSSION}

Monitoring and phytopathological diagnosis of diseases in garden bean crops over the years has shown that viral and bacterial diseases are of great importance in the cultivation of this crop (Table 1). Every year in the crops of garden beans appear bacteriosis bacterial and halo blight. Bacteriosis causes a great damage to crop and seed production in this crop. Bacteria are stored in the seeds for many years; they reduce laboratory and field germination, cause rot and mass death of seedlings. The development of bacterial diseases not only reduces the yield of beans, but also degrades the quality of production. The degree of attack and their development depends on the climatic conditions during the growing season.

Most local varieties of garden beans are susceptible to attack by bacterial diseases (Georgieva \& Sofkova, 2014). Of the two bacterial diseases, bacterial blight Xap is more harmful.

As a result of our research, it was found that bacterial blight is a major disease of organic garden beans. It is believed that halo blight is more widespread in the northern regions due to the resistance of the pathogen to lower temperatures (Luchnaya, 2010). The high summer temperatures during the reporting period and the use of genetic material with resistance to races 1 and 2 of Pseudomonas savastanoi $p v$. phaseolicola can be cited as reasons for the lower development of this disease in beans in our experiment.

The results of disease monitoring in snap bean crops for organic production showed that the first symptoms of the disease appear after the germination of beans and develop massively in the flowering phases - the beginning of bean maturation (table 2). The infestation index of bacterial blight during the vegetation varies in the range from $1.78 \%$ to $10 \%$ in both varieties.

Of the fungal diseases during the years of the experiment, Fusarium wilt and anthracnose were reported with Fusarium solani f. faseoli and Colletotrichum lindemuthianum diagnosed by microscopy. The development of rust during the years of the experiment was not found.

The comparison of the two technologies for growing beans showed that timely spraying with Bordeaux Mix 20VP 300g / Da has an equivalent protective effect against the development of diseases transmitted by seed bacteriosis and anthracnose. The results obtained from the monitoring of diseases in the crop treated with the fungicide Bordeaux Mix do not differ from those in the crop treated with the fungicides - Bordeaux Mix 20VP $300 \mathrm{~g} / \mathrm{Da}$, Fuguran 50VP $300 \mathrm{~g} / \mathrm{Da}$ and Topaz 100 EK 50 $\mathrm{ml} / \mathrm{Da}$ (table 3 ).

As a result of our assessment of the Bulgarian varieties of snap bean "Evros" and "Tangra", no significant varietal differences were found in terms of resistance to seed-borne diseases. The "Euros" and "Tangra" varieties show relative resistance to the pathogens Xantomonas axanopodis pv. phaseoli and Colletotrichum lindemuthianum but are strongly attacked by viral diseases. The development of bacteriosis and anthracnose with the triple use of the fungicide Bordeaux Mix 20VP, approved in the organic cultivation of vegetable crops, with an interval of 14 days, starting from the flowering phase, is in the range of up to $12.5 \%$ in both varieties. The attack of viral diseases was significantly lower in snap bean grown using conventional technology, which involves the use of an 
75 years of Agricultural University - Plovdiv JUBILEE SCIENTIFIC INTERNATIONAL CONFERENCE Plovdiv 26-28 November 2020
PERSPECTIVES ON AGRICULTURAL SCIENCE AND INNOVATIONS FOR SUSTAINABLE FOOD SYSTEMS extended range of pesticides. This result is causally related to the effectiveness of the insecticides used to treat viral vectors.

The selection of a variety suitable for organic production is based on several main indicators. One of the most important indicators is yield. The biological potential for yield in modern indeterminate varieties is 4-5 $\mathrm{Tn} / \mathrm{Da}$, and in determinant - 2.5-3 Tn of green beans per acre (Poryazov, 1990). In our experiment the real yield of the variety "Tangra" was $2091 \mathrm{~kg} / \mathrm{Ha}$ and $4296 \mathrm{~kg} / \mathrm{Ha}$ for the "Evros" variety, respectively.

The productivity of the "Tangra" variety is $83.0 \mathrm{~g}$ per plant, of the "Evros" variety $143 \mathrm{~g}$ per plant respectively.

Early ripening is an important selection trait, which in temperate latitudes determines the ability of varieties to avoid high summer temperatures combined with low humidity - a major factor in the abortion of flowers in bean plants. The indicators of early maturity in the "Tangra" variety are 46 days and 51 days in the "Evros" variety.

According to the complex of valuable agro-ecological, economic characteristics and the resistance to bacterial blight and anthracnose, the "Evros" variety has shown stable adaptability to the growing conditions using the technology for organic production.

\section{CONCLUSIONS}

Seed-borne diseases - viral mosaics, bacterial blight and anthracnose are the main diseases of snap bean for organic production.

The timely use of copper fungicide -
Bordeaux mixture for the treatment of plants during the growing season against bacterial blight and anthracnose gives satisfactory results.

A comparison of conventional and biological plant protection systems for growing beans shows that the enrichment of the list of fungicides used does not significantly affect the degree of development of seed-borne diseases in beans.

In organic bean cultivation, viral diseases have a significantly stronger development than conventional ones. This requires the use of highly effective biological insecticides against vectors of viral infection.

No significant varietals differences were found in the varieties "Evros" and "Tangra" on the grounds of resistance to bacterial blight and anthracnose in the cultivation of the crop by biological technology.

According to the complex of economic indicators and the degree of its resistance to major diseases, the "Evros" variety can be characterized as an adaptive Bulgarian variety for cultivation by biological technology.

The experiment shows that in organic crops, preventive control measures are the most important. They are aimed at complying with the following conditions: using certified disease-free seed, crop rotation, control volunteer beans and eliminate weeds that may act as reservoir hosts for the bacteria, fungicide/bactericide treatments, if the disease is present and weather conditions favor its development. 
75 years of Agricultural University - Plovdiv JUBILEE SCIENTIFIC INTERNATIONAL CONFERENCE Plovdiv 26-28 November 2020
PERSPECTIVES ON AGRICULTURAL SCIENCE AND INNOVATIONS FOR SUSTAINABLE FOOD SYSTEMS

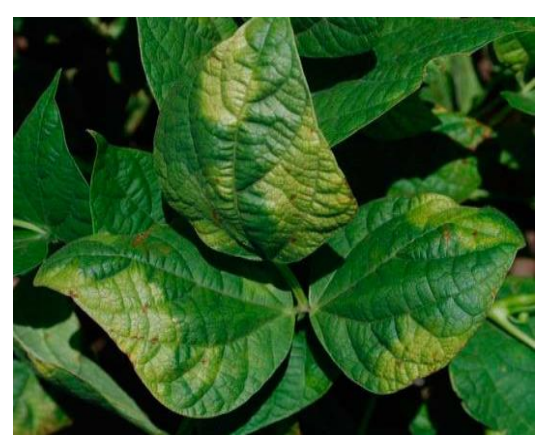

$\mathbf{a}$

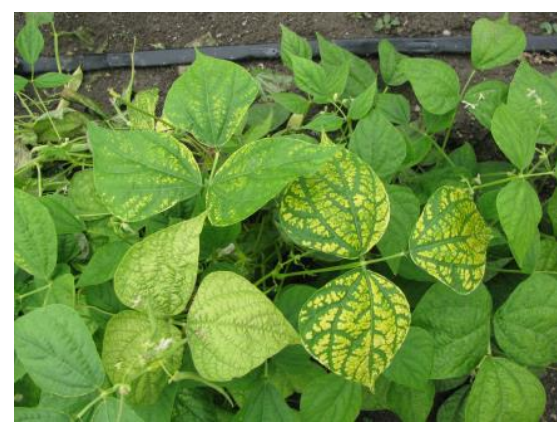

b

Pict. 3. Diseases of snap bean- Bacterial blight (a) and Bean yellow mosaic virus (b)

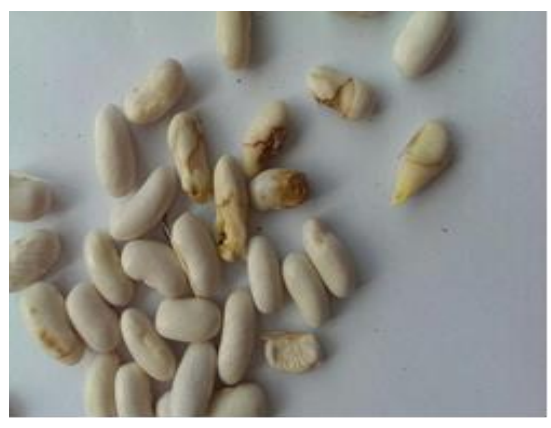

$\mathbf{a}$

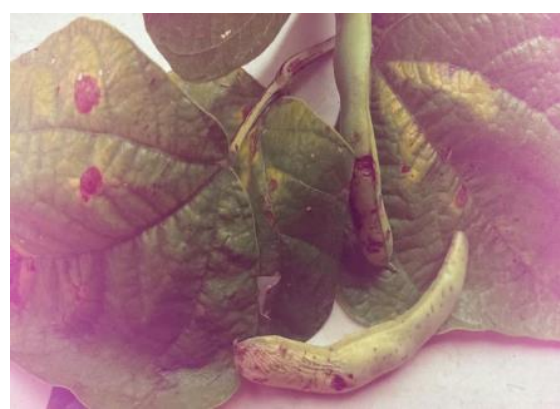

b

Pict. 4. Bacterial blight Xantomonas campestris pv. phaseoli - symptoms of bacterial blight on snap bean seeds (a) and damage leaves and beans (b).

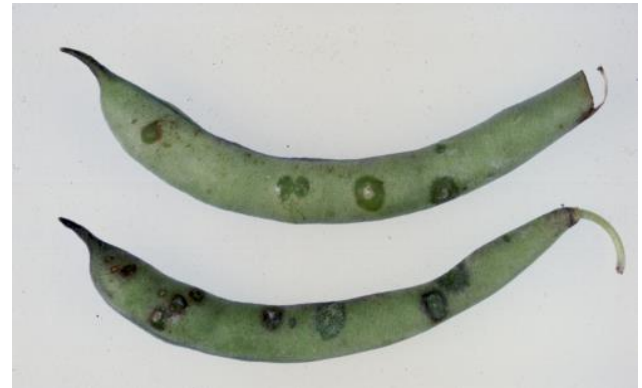

a

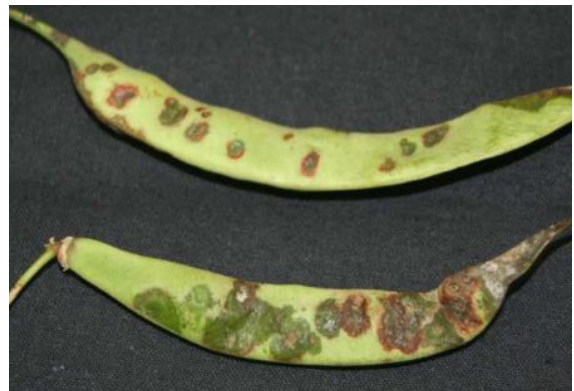

b

Pict. 5. Halo blight Pseudomonas syringae pv. phaseolicola and Anthracnose Colletotrichum lindemuthianum. 
75 years of Agricultural University - Plovdiv JUBILEE SCIENTIFIC INTERNATIONAL CONFERENCE Plovdiv 26-28 November 2020
PERSPECTIVES ON AGRICULTURAL SCIENCE AND INNOVATIONS FOR SUSTAINABLE FOOD SYSTEMS

Table 1. Economically important pathogens of snap bean in the Plovdiv region.

\begin{tabular}{|c|c|c|}
\hline Microorganism & Disease & $\begin{array}{c}\text { Spread, } \\
\text { harmfulness }\end{array}$ \\
\hline Bean common mosaic virus-BCMV & Bean common mosaic virus & +++ \\
\hline Bean yellow mosaic virus-BYMV & Bean yellow mosaic virus & +++ \\
\hline Cucumber mosaic cucumovirus-CMV & Cucumber mosaic cucumovirus & ++ \\
\hline $\begin{array}{l}\text { Xantomonas campestris pv. phaseoli } \\
\text { (Smith) }\end{array}$ & Bacterial blight & +++ \\
\hline $\begin{array}{l}\text { Pseudomonas syringae pv phaseolicola } \\
\text { (Burkhoider) Dowson. }\end{array}$ & Halo blight & ++ \\
\hline Fusarium solanif. faseoli Burkholde & Fusarium root rot & ++ \\
\hline $\begin{array}{l}\text { Colletotrichum lindemuthianum Saccardo } \\
\text { et Magnus }\end{array}$ & Antracnose & +++ \\
\hline Uromyces appendiculatus Strauss & Rust & + \\
\hline
\end{tabular}

Symbols: (+++) - causes damage almost every year; $(++)$ - causes serious damage in some years; (+-) -occurs sporadically, only in the presence of conditions suitable for development; $(-)$ - no disease has been identified for the region.

Table 2. Development of bacterial and viral diseases in the snap bean grown for organic farming (average indicators for two years).

\begin{tabular}{|c|l|l|l|l|l|l|}
\hline \multirow{2}{*}{$\begin{array}{c}\text { Variety / } \\
\begin{array}{c}\text { Development } \\
\text { phase }\end{array}\end{array}$} & \multicolumn{2}{|c|}{ Two pairs of true leaves } & \multicolumn{2}{c|}{ Mass flowering } & \multicolumn{2}{c|}{ Mass formation of beans } \\
\cline { 2 - 7 } & Bacterial & $\begin{array}{l}\text { Bean } \\
\text { yellow } \\
\text { mosaic } \\
\text { virus }\end{array}$ & $\begin{array}{l}\text { Bacterial } \\
\text { blight }\end{array}$ & $\begin{array}{l}\text { Bean } \\
\text { yellow } \\
\text { mosaic } \\
\text { virus }\end{array}$ & $\begin{array}{l}\text { Bacterial } \\
\text { blight }\end{array}$ & $\begin{array}{c}\text { Bean } \\
\text { yellow mosaic } \\
\text { virus }\end{array}$ \\
\hline "Evros" & 1,76 & 4,94 & 3,24 & 13,81 & 9,5 & 42,25 \\
\hline "Tangra" & 2,86 & 5,39 & 3,38 & 15,67 & 16,75 & 41,00 \\
\hline
\end{tabular}

Table 3. Development of bacterial and viral diseases in snap bean grown according to conventional technology (average values over two years).

\begin{tabular}{|c|l|l|l|l|l|l|}
\hline \multirow{2}{*}{$\begin{array}{c}\text { Variety / } \\
\begin{array}{c}\text { Development } \\
\text { phase }\end{array}\end{array}$} & \multicolumn{2}{|l|}{ Two pairs of real leaves } & \multicolumn{2}{l|}{ Mass flowering } & \multicolumn{2}{l|}{ Mass formation of beans } \\
\cline { 2 - 7 } & $\begin{array}{l}\text { Bacterial } \\
\text { blight }\end{array}$ & $\begin{array}{l}\text { Bean } \\
\text { yellow } \\
\text { mosaic } \\
\text { virus }\end{array}$ & $\begin{array}{l}\text { Bacterial } \\
\text { blight }\end{array}$ & $\begin{array}{l}\text { Bean } \\
\text { yellow } \\
\text { mosaic } \\
\text { virus }\end{array}$ & $\begin{array}{l}\text { Bacterial } \\
\text { blight }\end{array}$ & $\begin{array}{l}\text { Bean yellow } \\
\text { mosaic virus }\end{array}$ \\
\hline "Evros" & 1,25 & 2,5 & 2,89 & 2,96 & 6,56 & 11,33 \\
\hline "Tangra" & 3,85 & 3,98 & 1,52 & 4,67 & 3,57 & 13,91 \\
\hline
\end{tabular}


75 years of Agricultural University - Plovdiv JUBILEE SCIENTIFIC INTERNATIONAL CONFERENCE Plovdiv 26-28 November 2020
PERSPECTIVES ON AGRICULTURAL SCIENCE AND INNOVATIONS FOR SUSTAINABLE FOOD SYSTEMS

Table 4. Biological potential of snap bean varieties "Evros" and "Tangra".

\begin{tabular}{|c|c|c|c|}
\hline Variety & Productivity, g/plant & Yield, kg/Ha & Early maturity, days \\
\hline "Evros" & 143,20 & 4296,00 & 51 \\
\hline "Tangra" & 83,65 & 2091,25 & 46 \\
\hline
\end{tabular}

Table 5. Development of symptoms of bacterial and fungal diseases on snap bean seeds.

\begin{tabular}{|c|c|c|c|c|}
\hline \multirow{2}{*}{ Year } & \multirow{2}{*}{ Variant/Variety } & \multicolumn{2}{|c|}{ Diseased seeds, $(\%)$} & \multirow[t]{2}{*}{ Non-standard seeds, $(\%)$} \\
\hline & & Bacterial blight & Antracnose & \\
\hline \multicolumn{5}{|c|}{ Organic farming } \\
\hline \multirow[t]{4}{*}{1} & "Evros" & 13,12 & 0,68 & 13,80 \\
\hline & "Evros" & 25,00 & 3,00 & 4,00 \\
\hline & "Tangra" & 10,25 & 1,25 & 11,50 \\
\hline & "Tangra" & 14,00 & 0,00 & 5,00 \\
\hline \multicolumn{5}{|c|}{ Conventional cultivation } \\
\hline \multirow[t]{4}{*}{2} & "Evros" & 48 & 14 & 18,53 \\
\hline & "Evros" & 20,00 & 5,00 & 7,00 \\
\hline & "Tangra" & 6,38 & 4,29 & 10,67 \\
\hline & "Tangra" & 5,00 & 0,00 & 4,00 \\
\hline
\end{tabular}

\section{ACKNOWLEDGMENT}

This work was supported by the Bulgarian Ministry of Education and Science under the National Research Program "Healthy Foods for a Strong Bio-Economy and Quality of Life" approved by DCM 577/7.08.2018.

\section{REFERENCES}

Abi Soares dos Anjos Marques. 2016. Population dynamics of Pseudomonas savastanoi pv. phaseolicola in bean, throughout the epiphytic and pathogenic phases. Pesquisa Agropecuaria Brasileira. 51(5):623630.

Akhter, W., M. Bhuiyan, F. Sultana, M. Hossain. 2015. Integrated effect of microbial antagonist, organic amendment, and fungicide in controlling seedling mortality (Rhizoctonia solani) and improving yield in pea (Pisum sativum L.). Comptes Rendus Biologies, 338, 21-28.
Budanova, V.I. 1986. The use of sources and donors of resistance to disease in bean breeding. Works of All-Union Institute of Plant Breeding, Issue. v. 159 (3), pp. 38-41 (Ru).

Buravtseva, T., L. Lagutina, M. Gurkina. 2009. Estimation of a new source material of common beans from the VIR collection and selection of sources of economically valuable features // Collection of scientific materials of VNIIZBK $(\mathrm{Ru})$.

Chekalin, N. 2003. Genetic bases of selection of legumes for resistance to pathogens. Poltava, 186 p. $(\mathrm{Ru})$.

Chavan, J.; L.Kute, S. Kadam. 1989. Soybean. In: (Eds. Salunkhe, D.D.; Kadam, S.S.). CRC Handbook of world food legumes. Boca Raton: CRC Press, pp. 223 -245.

El-Mohamedy, S. \& M. Abdel Alla. 2013. Biopriming seed treatment for biological control of soil borne fungi causing rootrot of green bean (Phaseolus vulgaris L.). J. of Agric. Technol., 9 (3): 589 - 
75 years of Agricultural University - Plovdiv

JUBILEE SCIENTIFIC INTERNATIONAL

CONFERENCE Plovdiv 26-28 November 2020
PERSPECTIVES ON AGRICULTURAL SCIENCE AND INNOVATIONS FOR SUSTAINABLE FOOD SYSTEMS
599.

Fadeev, $\quad Y u$. 1977. Methods of phytopathological research in plant breeding., Moskow. (Ru).

Finckh M. \& A. van Bruggen. 2015. Organic production of annual crops. In: Plant diseases and their management in organic agriculture (ed. by Finckh $M$. et $a l$.). APS PRESS, $424 \mathrm{p}$.

Gent, D. \& H. Schwartz. 2005. Management of Xanthomonas leaf blight of onion with a plant activator, biological control agents, and copper bactericides. Plant Dis. 89, 631-639.

Georgieva, O. \& S. Sofkova. 2014. Field screening of vegetable bean varieties (Phaseolus vulgaris L.) for valuable economic characteristics and resistance to brown bacteriosis Xantomonas axanopodis pv phaseoli (Smith). Collection of scientific works. VNIISSOK, Moscow. Issue 45, pp. 200-211.

González, A., E. Landeras. 2004. Pseudomonas savastanoi pv. phaseolicola (Burk) Gardan et al. \& Pseudomonas syringae pv. syringae Van Hall. In Book Fichas de diagnóstico en laboratorios de organismos nocivos de los vegetales Editors: Ministerio de Agricultura Pesca y Alimentación. 232 p.

Kiryakov, I. 2000. Racial diversity of Colletotrichum lindemuthianum in Bulgaria. Plant Science, v 37: 248-251.

Kiryakov, I., D. Genchev. 2002. Sources of resistance to the main diseases for Bulgaria in ripe beans (Phaseolus vulgaris L.) in the collection of Dobrudzha Agricultural Institute. Scientific papers from the Jubilee scientific session "50 years of Dobrudzha Agricultural Institute, Selection and agrotechnics of field crops". v 1: 251-260. (Bg).

Kiryakov, I., D. Genchev. 2003. Bean Rust
Races in Northeastern Bulgaria in 2002. Scientific Message of SUB. Dobrich. v. 5: 72-76. (Bg).

Kiryakov, I., D. Genchev. 2004. New races of anthracnose on beans in Bulgaria. Research on field crops. v.1-2: 336-341.

Kling, A. 2010. Estimation of collection samples of vegetable beans (Phaseolus vulgaris L.) and creation of initial material for its selection in southern forest-steppe of Western Siberia: the dissertation. Omsk, 142 p. (Ru).

Latorre, B. \& A. Jones. 1979. Evaluation of weeds and plant refuse as potential sources of inoculum of Pseudomonas syringae in bacterial canker of cherry. Phytopathology v. 69: 1122-1125.

Luchnaya, I. 2010. Selection value of bean samples for disease resistance in the conditions of the eastern part of the Forest-Steppe of Ukraine. - Manuscript Kharkov, 187 p. (Ru).

Mckinney, H.H. 1923. A new system of grading plant diseases. J. Agric. Res., v. 26: 195-218.

Pakhnenko, E. 2001. The value of soil and fertilizers in plant resistance to pathogenic fungi in agrocenoses. Diss. PhD, RF 06.01.04. Moscow.

Petrenkova, V., T. Markova, I. Lugovaya. 2009. Determination of resistance of beans to diseases and pests: Identification of signs of legumes. Moscow. 552 p. (Ru).

Pivovarov, V.F. 2013. The main directions and results of selection and seed production of vegetable legumes in VNIISSOK. In Book: "Vegetables of Russia". Moscow. Issue 1 (13):4-11. (Ru).

Poryazov, I. 1990. Selection studies in green beans. Habilitation thesis for awarding the scientific title "Senior Research Fellow I degree". Agricultural Academy, Sofia. (Bg).

Semenov A., A. Glinushkin, M. Sokolov.2016. Organic Agriculture and Health of Soil 
75 years of Agricultural University - Plovdiv JUBILEE SCIENTIFIC INTERNATIONAL

Ecosystem. Dostizheniya nauki i tekhniki APK. 2016. v. 30 (8): 5-8 $(\mathrm{Ru})$.

Singh, S. P. 2006. Common Bean (Phaseolus vulgaris L.), chapter In Genetic Resources, Chromosome Engineering, and Crop Improvement: Vegetable Crops, Vol. 3 by Ram J. Singh, CRC Press, $552 \mathrm{p}$.

Sofkova-Bobcheva S., O. Georgieva, G. Pevicharova, V. Petkova. 2014. Complex Analysis of introduced snap bean (Phaseolus vulgaris L.) genotypes for breeding. House of Science and Technique, Plovdiv, 5 June 2014. pp. 181-188.

Stancheva I. 2001. Atlas of Crop Diseases. Volume 3: Diseases of field crops. Sofia. 186. pp. 93-110.

Van Bruggen A. \& A. Semenov. 2000. In search of biological indicators for soil health and disease suppression. Appl. Soil Ecol., v. 15:13-24.

Vauterin L., J. Rademaker, J. Swing. 2000. Synopsis on the taxonomy of the genus Xanthomonas axanopodis pv. phaseoli. Phytophatology. v. 90:677-682.

Van Diepeningen A., O. de Vos, J. Korthals, A. van Bruggen. 2006. Effect of ogranic versus conventional management of chemical and biological parameters in agricultural soils. Appl. Soil Ecol. v. 31:120-135. 